\title{
Antiherpesvirus Activity in Human Sera and Urines after Administration of Adenine Arabinoside
}

\author{
IN VITRO AND IN VIVO SYNERGY OF ADENINE ARABINOSIDE AND \\ ARABINOSYLHYPOXANTHINE IN COMBINATION
}

\author{
Keith J. Champney, Carl B. Lauter, Elizabeth J. Bailey, and \\ A. Martin Lerner, Hutzel Hospital Medical Unit, Department of Medicine, \\ Wayne State University School of Medicine, Detroit, Michigan 48201
}

\begin{abstract}
A B S T RACT The minimum inhibitory concentration (MIC) of adenine arabinoside (ara-A) in rabbit kidney microtiter tissue cultures (RK-13) to a prototype strain of herpes simplex virus, type 1 (E115) based upon inhibition of cytopathic effects is $1.5 \mu \mathrm{g} / \mathrm{ml}$. In this system, the MIC of arabinosylhypoxanthine (ara$\mathrm{Hx}$ ), the major in vivo metabolic derivative of ara-A, is $75 \mu \mathrm{g} / \mathrm{ml}$. Inhibition of cytopathic effects of herpes simplex virus, type 1 (HSV-1) in microtiter wells of RK-13 cells varies directly with the concentrations of ara-A or ara-Hx, and inversely with residual HSV-1. The MIC of ara-A for HSV-1 in RK-13 cells is 5-20 times lower than similar measures with vero renal, mouse embryo, or human foreskin cultures. With RK13 tissue cultures in microtiter plates, an assay for "ara-A equivalents" in human body fluids was developed which compares in sensitivity with high pressure liquid chromatography and has the advantage of simultaneously measuring combined antiherpesvirus effects of ara-A and its major metabolic derivative, ara-Hx.
\end{abstract}

These data were presented in part at a symposium honoring the 60th birthday of Dr. Edward H. Kass at the Harvard Club, Harvard Medical School, Boston, Mass. on 16 and 17 December 1977. They were also presented at the annual meeting of the Interscience Conference on Antibiotics and Chemotherapy in New York on 9-14 October 1977, and at a workshop of the Antiviral Substances Group of the National Institute of Allergy and Infectious Diseases in Bethesda, Md. on 12 and 13 January 1978.

This study was performed during Dr. Champney's tenure as Fellow in Medicine and National Institute of Allergy and Infectious Diseases Trainee in Infectious Diseases. Dr. Champney is Director of Internal Medicine Education and Acting Chief of Infectious Diseases, Hurley Medical Center, Flint, Mich. 48502.

Received for publication 30 January 1978 and in revised form 24 July 1978.
In vitro checkerboard studies in RK-13 cells confirmed that ara-A and ara-Hx in combination had antiviral effects which are synergistic. The total of the fractional MIC of ara-A plus ara-Hx in combination also varies inversely with residual HSV-1 in microtiter wells. Because virus adsorption is complete at $2 \mathrm{~h}$ before specimens to be tested are added in this assay, and because human interferon is not measured in rabbit cells, the antiviral assay is not affected by the presence of type-specific antiherpesvirus antibody or human interferon.

Antiviral activity (AVA) was assayed as ara-A equivalents in sera and urines from 10 patients with serious herpesvirus infections who received $2.5-20 \mathrm{mg} / \mathrm{kg}$ daily of ara-A by intramuscular or intravenous routes. When a dosage schedule of $10 \mathrm{mg} / \mathrm{kg}$ per day or more was used, sustained concentrations of AVA that ranged from 0.8 to $14.4 \mu \mathrm{g} / \mathrm{ml}$ were found. When an inhibitor of adenosine deaminase (covidarabine) was not added to the specimens, mean serum concentrations were $\cong 3.0 \mu \mathrm{g} / \mathrm{ml}(10 \mathrm{mg} / \mathrm{kg}$ per day, i.v. $)$, and $4.1 \mu \mathrm{g} / \mathrm{ml}(20$ $\mathrm{mg} / \mathrm{kg}$ per day). However, in a single patient given $20 \mathrm{mg} / \mathrm{kg}$ of ara-A daily with covidarabine immediately added to the sera, the mean concentration of AVA was $12.9 \mu \mathrm{g} / \mathrm{ml}$. Urines contained even higher AVA. Assays of 19 sera were performed both by microbiologic assay for AVA and by high pressure liquid chromatography for ara-A and ara-Hx. AVA was greater by microbiologic assay, and was greater than that which could be accounted for by stoichiometric chromatographic measures of ara-A and ara-Hx. These results with sera of treated patients are consistent both with the in vitro synergy of ara-A and ara-Hx found by checkerboard titrations, and with the beneficial responses to ara-A of patients with herpesvirus infections reported here and elsewhere. 


\section{INTRODUCTION}

Adenine arabinoside (9- $\beta-\mathrm{D}$ arabinofuranosyladenine, ara- $A^{1}$, or vidarabine) is an effective antiherpesvirus agent. Ara-A is therapeutic for patients with keratouveitis (1) and encephalitis (2) caused by herpes simplex viruses as well as in disseminated varicella-zoster in the immunosuppressed (3). Controlled trials of ara-A in neonatal herpes simplex virus encephalitis are not yet complete $(4,5)$. Results have been less promising in variola major (6) and cytomegalovirus infections (7).

In the past, this laboratory's biological assays of pharmacokinetics of ara-A in human body fluids have been too insensitive to be useful (8), and correlations of clinical experience and concentrations of drug have depended upon chemical studies $(9,10)$. In this regard, our earlier microbiologic assays of human body fluids had a sensitivity of $\cong 20 \mu \mathrm{g} / \mathrm{ml}$ of ara-A. When used, only 1 of 84 sera from patients who had received up to $20 \mathrm{mg} / \mathrm{kg}$ i.v. daily had detectable concentrations (8). We now report results of reassaying these same specimens by a new method with a sensitivity of $1.5 \mu \mathrm{g} / \mathrm{ml}$ of ara-A.

\section{METHODS}

Administration of ara-A and collections of specimens. After informed consent, 10 patients with various herpesvirus infections were given ara-A for 5-10 days in graded doses from 2.5 to $20.0 \mathrm{mg} / \mathrm{kg}$ per day by i.m. (2 patients) or i.v. routes. Ara-A was infused intravenously at rates of $16-75 \mathrm{mg} / \mathrm{h}$. Diagnoses were severe recurrent genital herpes simplex virus, type 2 infection, 1 patient; disseminated HSV-1 infection, 2 patients; severe localized varicella-zoster $(\mathrm{V}-\mathrm{Z})$ infection, 2 patients; congenital cytomegalovirus infection, 1 patient; disseminated $\mathrm{V}-\mathrm{Z}$ infection, 2 patients; chicken pox, 1 patient; and HSV-1 encephalitis, 1 patient. Single daily i.m. injections were given to two patients, and others received continuous i.v. infusions in $5 \%$ glucose solutions at a ratio of $\geq 2 \mathrm{ml} / \mathrm{mg}$. Intravenous infusions of ara-A were given at rates varying from 16 to $75 \mathrm{mg} / \mathrm{h}$ for 5-10 days (Table I). Intravenous infusions were given continuously but the rates of administration were not otherwise specifically controlled. Before ara-A infusions were begun, samples of blood and urine were collected from each patient. No antiviral activity (AVA) was detected in these specimens. In previous studies, we had shown that measures of AVA as determined here were unaffected by neutralizing antibody when specimens were added after absorption of virus was complete (e.g., 2 h later) (11). At intervals, thereafter, bloods were taken, refrigerated $\left(4^{\circ} \mathrm{C}\right)$ until clotted, and sera were separated. Bloods from patients 1-9 were handled promptly. With patient $10,50 \mu \mathrm{g}$ of an inhibitor of adenosine deaminase ${ }^{2}$ (co-ara-A or covidarabine, DI) was

${ }^{1}$ Abbreviations used in this paper: ara-A, adenine arabinoside; ara-Hx, arabinosylhypoxanthine; AVA, antiviral activity; CPE, cytopathic effects; HPLC, high pressure liquid chromatography; HSV-1, herpes simplex virus, type 1; MIC, minimum inhibitory concentration(s); $\mathrm{TCD}_{50}$, fifty percent tissue culture dose; V-Z, varicella zoster.

${ }^{2} \mathbf{R}$ - 3 - (2 - deoxy - $\beta$ - D - erythro - pentofuranosyl) - 3,5,7,8 tetrahydroimidazo-(4,5-d)-(1,3)-diazepin-8-al. Parke, Davis \& Company, Detroit, Mich. added for each $10 \mathrm{ml}$ of whole blood $(12,13) .{ }^{3}$ When covidarabine was added in this concentration, it had no AVA (12). Total urinary collections in 4- to 6 -h aliquots were also saved $\left(4^{\circ} \mathrm{C}\right)$. Until assay, sera and urines were stored $\left(-20^{\circ} \mathrm{C}\right)$.

Clinical findings. During infusions of ara-A, hematologic (hemoglobin, hematocrit, total leukocyte and differential counts, erythrocytic indices, and platelet count), serum aspartate aminotransferase, serum alanine aminotransferase liver (alkaline phosphatase, cholesterol, prothrombin time, and albumin), and renal (creatinine and blood urea nitrogen) functions were tested every 2 nd day. Thereafter, tests were followed less frequently. Patients were examined daily by us. Standard electrocardiograms were done every 3rd day.

When considering cutaneous $\mathrm{V}-\mathrm{Z}$ or herpes simplex virus infections, the disease was considered disseminated when 20-100 vesicles appeared at sites different from the primary dermatome(s); or with congenital cytomegalovirus infection, when evidence of liver dysfunctions appeared. No patient received ara-A and concomitant radiation or cytotoxic drugs. Corticosteroids were continued at maintenance dosages during treatment with ara-A if needed for the primary underlying conditions. Cutaneous lesions were considered to have cleared when crusts had fallen off, leaving erythematous macules.

Virologic and antibody methods. Isolation, passage, and quantitation of HSV-1 and V-Z viruses; immunotyping of strains and meaures of micro-passive hemagglutinating, complement fixing, and indirect immunofluorescent antibodies have been described in detail earlier $(14,15)$.

Antiviral activity in sera and urines. A microtiter method and various tissue cultures were used for determining minimum inhibitory concentrations (MIC) with a single strain (E115) ${ }^{4}$ of HSV-1. Mean values were $37 \mu \mathrm{g} / \mathrm{ml}$ (human foreskin fibroblasts); $7.5 \mu \mathrm{g} / \mathrm{ml}$ (mouse embryo fibroblasts and vero renal cells); and, interestingly, $1.5 \mu \mathrm{g} / \mathrm{ml}$ (rabbit renal cells, RK-13, Flow Laboratories, Inc., Rockville, Md). Therefore, because of its unique susceptibility to the antiviral effects of ara-A for HSV-1 (E115), we used RK-13 tissue cultures to assay ara-A in human body fluids.

Monolayers of rabbit kidney cells were prepared in microtiter II plates (Falcon Plastics, Division of BioQuest, Oxnard, California). $0.1 \mathrm{ml}$ of HSV-1 containing $10^{3.5} \mathrm{TCD}_{50}$ (fifty percent tissue culture doses) was added to each well. This inoculum had previously been shown to cause complete $(4+)$ dissolution of the tissue cultures after $48 \mathrm{~h}$. Plates were sealed with Falcon pressure sensitive film (Falcon Plastics) and incubated for $2 \mathrm{~h}\left(37^{\circ} \mathrm{C}\right)$ allowing virus to be absorbed to RK-13 cells and, thus, virus was unaffected by presence of serum antibody in specimens (11). Unabsorbed virus was then decanted. Before inoculations, specimens were diluted with Eagle's minimum essential medium containing $2 \%$ fetal calf serum, and a final concentration of $10 \mu \mathrm{g} / \mathrm{ml}$ of co-ara-A was added. Covidarabine at this concentration had no antiviral activity (12). $0.1 \mathrm{ml}$ of diluted specimens was added to each well. Serum was diluted beginning at $1: 2$, urine starting at 1:5. Each day, experiments had wells with known concentrations of ara-A. MIC for ara-Hx were $75-150 \mu \mathrm{g} / \mathrm{ml}$. Concentrations of $6.0 \mu \mathrm{g} / 0.1 \mathrm{ml}$ (ara-A) and $30 \mu \mathrm{g} / 0.1 \mathrm{ml}$ (ara-Hx) were toxic to RK-13 cells. However, at MIC for ara-A, there was only $0.15 \mu \mathrm{g} / 0.1 \mathrm{ml}$ of ara-A and $7.5-15 \mu \mathrm{g} / 0.1 \mathrm{ml}$ of ara- $\mathrm{Hx}$, and these concentrations did not visibly alter the tissue cultures. Wells containing ara-A and ara-Hx also contained coara-A. After all wells were inoculated, plates were again sealed and incubated $\left(37^{\circ} \mathrm{C}\right)$ for $48 \mathrm{~h}$.

\footnotetext{
${ }^{3}$ Unfortunately, co-ara-A was not available to add to the bloods from patients $1-9$.

4 (HSV-1) E115 was obtained from the American Type Culture Collection, Rockville, Md.
} 
TABLE I

Clinical Findings in 10 Patients with Herpesvirus Infections Who Received Parenteral Ara-A

\begin{tabular}{|c|c|c|c|c|c|c|c|c|}
\hline Patient & Age & Sex & Infection* & Underlying conditions & & Ara-A & & Course \\
\hline & $y r$ & & & & $m g / k g / d a y$ & $m g / h$ & no. of day.s & \\
\hline 1 & 29 & $\mathbf{M}$ & $\begin{array}{l}\text { Recurrent genital } \\
\text { HSV-2: isolation of } \\
\text { virus (VF); PHA } \\
\text { 3-13-72, 1/640; } \\
\text { 4-25-72, 1/2,560 }\end{array}$ & None & 2.5 (i.m.) & - & 5 & - \\
\hline 2 & 9 & $\mathbf{M}$ & $\begin{array}{l}\text { Disseminated HSV-1; } \\
\text { Tzanck +; isolation } \\
\text { of virus (VF) PHA } \\
3-24 \text { and 3-25-72, } \\
\geq 1 / 10,000\end{array}$ & $\begin{array}{l}\text { Lupus erythema- } \\
\text { tosus, recent } \\
\text { corticosteroid } \\
\text { therapy }\end{array}$ & 5 (i.m.) & - & 6 & $\begin{array}{l}\text { No new lesions after } \\
\text { day } 3 \text { of treatment; } \\
\text { clear by day } 6\end{array}$ \\
\hline 3 & 58 & $\mathbf{F}$ & $\begin{array}{l}\text { Ophthalmic herpes } \\
\text { zoster: Tzanck +, } \\
\text { (VF) }\end{array}$ & Ulcerative colitis & 10 (i.v.) & 22 & 10 & $\begin{array}{l}\text { Vesicles were no } \\
\text { longer forming at } \\
\text { start of ara-A; } \\
\text { decrease in pain } \\
\text { at } 5 \text { th day of treat- } \\
\text { ment }\end{array}$ \\
\hline 4 & 78 & $\mathbf{F}$ & $\begin{array}{l}\text { Perianal and sacral } \\
\text { herpes zoster }\end{array}$ & None & 10 (i.v.) & 16 & 10 & $\begin{array}{l}\text { Decrease in pain; no } \\
\text { new vesicles } \\
\text { appeared }\end{array}$ \\
\hline $\begin{array}{l}5 \mathrm{~A} \\
5 \mathrm{~B}\end{array}$ & 0.01 & $\mathbf{M}$ & $\begin{array}{l}\text { Congenital CMV: in- } \\
\text { clusions and isola- } \\
\text { tion of virus from } \\
\text { urine; elevated } \\
\text { IgM-IFA in sera; } \\
5-1-72,1 / 128 ; \\
5-7-72,1 / 128 \text { dis- } \\
\text { seminated herpes } \\
\text { zoster; Tzanck }+ \\
\text { (VF) }\end{array}$ & None & $\begin{array}{l}10 \text { (i.v.) } \\
20 \text { (i.v.) }\end{array}$ & $\begin{array}{l}1.7 \\
0.75\end{array}$ & $\begin{array}{r}5 \\
10\end{array}$ & $\begin{array}{l}\text { Unchanged viruria } \\
\text { continued }\end{array}$ \\
\hline 6 & 51 & $\mathbf{F}$ & $\begin{array}{l}\text { Disseminated herpes } \\
\text { zoster; Tzanck +, } \\
\text { (VF) }\end{array}$ & $\begin{array}{l}\text { Hodgkin's, stage } \\
\text { IVB, recent } \\
\text { anticancer chemo- } \\
\text { therapy }\end{array}$ & 20 (i.v.) & 70 & 9 & $\begin{array}{r}\text { No new lesions after } \\
\text { day } 3 \text { of treatment }\end{array}$ \\
\hline 7 & 53 & $\mathbf{M}$ & $\begin{array}{l}\text { Disseminated herpes } \\
\text { zoster:* Tzanck }+, \\
\text { virus isolated from } \\
\text { VF }\end{array}$ & $\begin{array}{l}\text { Hodgkin's, stage } \\
\text { IVB cancer of } \\
\text { larynx; recent } \\
\text { anticancer chemo- } \\
\text { therapy }\end{array}$ & 20 (i.v.) & 75 & 8 & $\begin{array}{l}\text { Lesions dry at } 7 \\
\text { days; clear by } 9 \\
\text { days }\end{array}$ \\
\hline 8 & 64 & $\mathbf{M}$ & $\begin{array}{l}\text { Disseminated } \\
\text { HSV-1: virus iso- } \\
\text { lated (VF) Tzanck } \\
\text { +, PHA, 6-8-72, } \\
\text { 1/5,120; 6-18-72, } \\
\geq 1 / 10,000\end{array}$ & $\begin{array}{l}\text { Lymphoma, } \\
\text { mycosis, } \\
\text { fungoides }\end{array}$ & 20 (i.v.) & 53 & 10 & $\begin{array}{l}\text { No new lesions after } \\
\text { 2nd day of treat- } \\
\text { ment }\end{array}$ \\
\hline 9 & 55 & $\mathbf{M}$ & $\begin{array}{c}\text { Chickenpox: Tzanck } \\
\quad+,(\mathrm{VF}) \mathrm{CF}, 1 / 250 \\
\text { 5-24 and } 6-4-72\end{array}$ & $\begin{array}{c}\text { Tuberculosis, dehy- } \\
\text { dration, azotemia }\end{array}$ & 20 (i.v.) & 55 & 10 & $\begin{array}{l}\text { No new lesions after } \\
4 \text { days of treat- } \\
\text { ment; clear in } 8 \\
\text { days }\end{array}$ \\
\hline
\end{tabular}


TABLE I (Continued)

\begin{tabular}{|c|c|c|c|c|c|c|c|c|}
\hline \multirow[t]{2}{*}{ Patient } & \multirow{2}{*}{$\frac{\text { Age }}{y r}$} & \multirow[t]{2}{*}{ Sex } & \multirow[t]{2}{*}{ Infection* } & \multirow[t]{2}{*}{ Underlying conditions } & \multicolumn{3}{|c|}{ Ara-A } & \multirow[t]{2}{*}{ Course } \\
\hline & & & & & $m g / k g / d a y$ & $m g / h$ & no. of days & \\
\hline 10 & 63 & $\mathbf{M}$ & $\begin{array}{l}\text { Herpes simplex virus } \\
\text { encephalitis: } \\
\text { 5-4-77: } \\
\text { PHA, S = 1/320; } \\
\text { CSF }=1 / 16 \\
\text { S/CSF }=20(24)\end{array}$ & $\begin{array}{l}\text { Generalized } \\
\text { atherosclerosis }\end{array}$ & 20 (i.v.) & 69 & 7 & $\begin{array}{l}\text { Progressive } \\
\text { deterioration to } \\
\text { death }\end{array}$ \\
\hline
\end{tabular}

* HSV-2, herpes simplex virus, type 2; CMV, cytomegalovirus; CF, complement fixing antibodies; PHA, passive hemagglutinating antibodies; IFA, indirect immunofluorescent antibodies; VF, vesicular fluid.

At this time, plates were opened and specimens were decanted. Cells were fixed with $10 \%$ formaldehyde and stained with paragon-formalin. Plates were then washed with tap water, and cytopathic effects (CPE) were read with a stereoscopic microscope. Wells showing $0-2+(50 \%$ of cells in a well showing CPE) CPE were considered to have AVC.

To correlate inhibition of CPE with decrements in herpes simplex virus replication as a result of ara-A or ara- $\mathrm{Hx}$, the following experiments were done. Routine MIC in RK-13 microtiter plates were run with ara-A and ara-Hx. At $48 \mathrm{~h}$ and before staining with paragon-formalin, cells and fluids from three wells each of virus and cell controls, as well as every concentration of ara-A (or ara-Hx) were scraped and pooled. Cell-fluid mixtures were rapidly freeze-thawed (three times) in acetone and dry ice, and titered for residual TCD $_{50}$ of HSV-1 in RK-13 microtiter plates as before (Fig. 1C). In these tests, the MIC to ara-A was again $1.5 \mu \mathrm{g} / \mathrm{ml}$, and for ara-Hx it was $75.0 \mu \mathrm{g} / \mathrm{ml}$. The virus control titered $10^{5.5} / 0.1 \mathrm{ml}$. With ara-A, pooled titers were $10^{2.5} \mathrm{TCD}_{30} / 0.1 \mathrm{ml}$ at an ara-A concentration of $0.6 \mu \mathrm{g} / 0.1 \mathrm{ml} ; 10^{3.5} \mathrm{TCD}_{50} / 0.1 \mathrm{ml}$ at $0.3 \mu \mathrm{g} / 0.1$ $\mathrm{ml} ; 10^{4.5} \mathrm{TCD}_{50} / 0.1 \mathrm{ml}$ at $0.15 \mu \mathrm{g} / 0.1 \mathrm{ml} ; 10^{5.3} \mathrm{TCD}_{50} / 0.1 \mathrm{ml}$ at $0.08 \mu \mathrm{g} / 0.1 \mathrm{ml} ; 10^{5.5} \mathrm{TCD}_{50} / 0.1 \mathrm{ml}$ at $0.04 \mu \mathrm{g} / 0.1 \mathrm{ml}$; and $10^{5.5}$ $\mathrm{TCD}_{5 \mathrm{o}} / 0.1 \mathrm{ml}$ at $0.02 \mu \mathrm{g} / 0.1 \mathrm{ml}$.

For ara-Hx, the virus control titered $10^{6.3} / 0.1 \mathrm{ml}$, there were $10^{1.5}, 10^{4.5}, 10^{5.8}, 10^{5.8}$, and $10^{6.3} \mathrm{TCD}_{50} / 0.1 \mathrm{ml}$ at concentrations of antiviral compound of $15,7.5,1.8,0.9$, and $0.4 \mu \mathrm{g} / 0.1$ $\mathrm{ml}$, respectively (Fig. 2). In this experiment, $15 \mu \mathrm{g} / \mathrm{ml}$ of araHx was not toxic to cell cultures. Thus, the titers of residual herpes simplex virus varied inversely with the concentrations of ara-A and ara-Hx in the pooled microtiter wells (Fig. 2). Cell controls contained no HSV-1. Therefore, in tests for MIC of ara-A and ara-Hx inhibition of CPE correlated with decreasing replication of herpes simplex virus in RK-13 tissue cultures (Figs. 1 and 2).

Estimations of the concentrations of AVA in patient specimens were made by calculations from the standard curve of that day's experiments considering the dilutions. Actual concentrations of AVA were, thus, measured per $0.1 \mathrm{ml}$, but are here expressed per milliliter. The sensitivity of the method was $1.5 \mu \mathrm{g} / \mathrm{ml}$ for ara-A and 75-150 $\mu \mathrm{g} / \mathrm{ml}$ for ara-Hx (16). Standard curves with known amounts of ara-A and ara-Hx were repeatedly reproducible as reported earlier with 5iodo-2'-deoxyuridine (11).

Each of the specimens of serum and urine which is reported here was run in duplicate, and each was repeated three times on separate days. Results by microbiologic assay were completely reproducible. In humans, ara-A is rapidly deaminated by adenosine deaminase to its hypoxanthine derivative, and sera, shortly after dosing, contain mostly ara-Hx, probably in combination with smaller amounts of ara-A $(9,10)$. The RK-13- method measures combined antiherpesvirus activity of the two antiviral compounds which we define as "ara-A equivalents" (Fig. 1).

High pressure liquid chromatography. Of the 77 specimens of sera assayed microbiologically here, 52 had been previously analyzed for ara-A and(or) ara-Hx by high pressure liquid chromatography (HPLC) by a Varian Aerograph model LC 4100 (Varian Associates, Instrument Div., Palo Alto, Calif.) through the courtesy of R. A. Buchanan (Parke, Davis \& Company, Detroit, Mich.). The sensitivity of this method was $0.1 \mu \mathrm{g} / \mathrm{ml}$ in plasma for ara-A and ara- $\mathrm{Hx}$ (10). No urines have been tested by HPLC for ara-A or ara-Hx.

In vitro microbiological assays of ara-A and ara-Hx in combination. When initial results of assays of AVA in patients' sera and urines yielded AVA which was greater than that predicted by HPLC, checkerboard titrations of fractions of the MIC of ara-A with ara-Hx in combination were done in RK-13 microtiter plates. Concentrations of ara-A and ara-Hx used in vitro in combination were well below those producing toxic cytopathology. MIC to ara-A and ara-Hx were also done in human serum with a high titer of passive hemagglutinating antibodies to HSV-1.

\section{RESULTS}

In vitro checkerboard assays of ara-A and ara-Hx in combination. A typical checkerboard titration in microtiter RK-13 plates with $10^{3.5} \mathrm{TCD}_{50} 0.1 \mathrm{ml}$ of $\mathrm{HSV}-1$ (E115) with combinations of ara-A and ara-Hx is shown in Table II. A decrease in CPE from $4+$ to $2+$ is considered to represent AVA. the minimum quantity of ara-A which, when combined with ara-Hx, showed AVA was $0.02 \mu \mathrm{g} / 0.1 \mathrm{ml}$ of ara-A combined with $1.8 \mu \mathrm{g} / 0.1$ $\mathrm{ml}$ of ara-Hx. Thus, in this titration, $0.13 \mathrm{MIC}$ of ara-A plus 0.25 MIC of ara-Hx equaled AVA equal to $1 \mathrm{MIC}$. The total of these fractional MIC for ara-A and ara- $\mathrm{Hx}$ required to yield AVA of 1 MIC of either compound was, thus, 0.38 ( 0.13 plus 0.25$)$. The "bonus" yield in AVA is $1-0.38$ or 0.62 MIC. We express this "bonus" as the "sparing factor". By earlier convention, a "sparing factor" $\geq 0.5$, we define as antiviral synergy (17).

Again, to show that inhibition of CPE of combinations of the fractions of MIC of ara-A and ara-Hx correlated with inhibition of virus multiplication, virus control and residual virus from wells with synergistic 

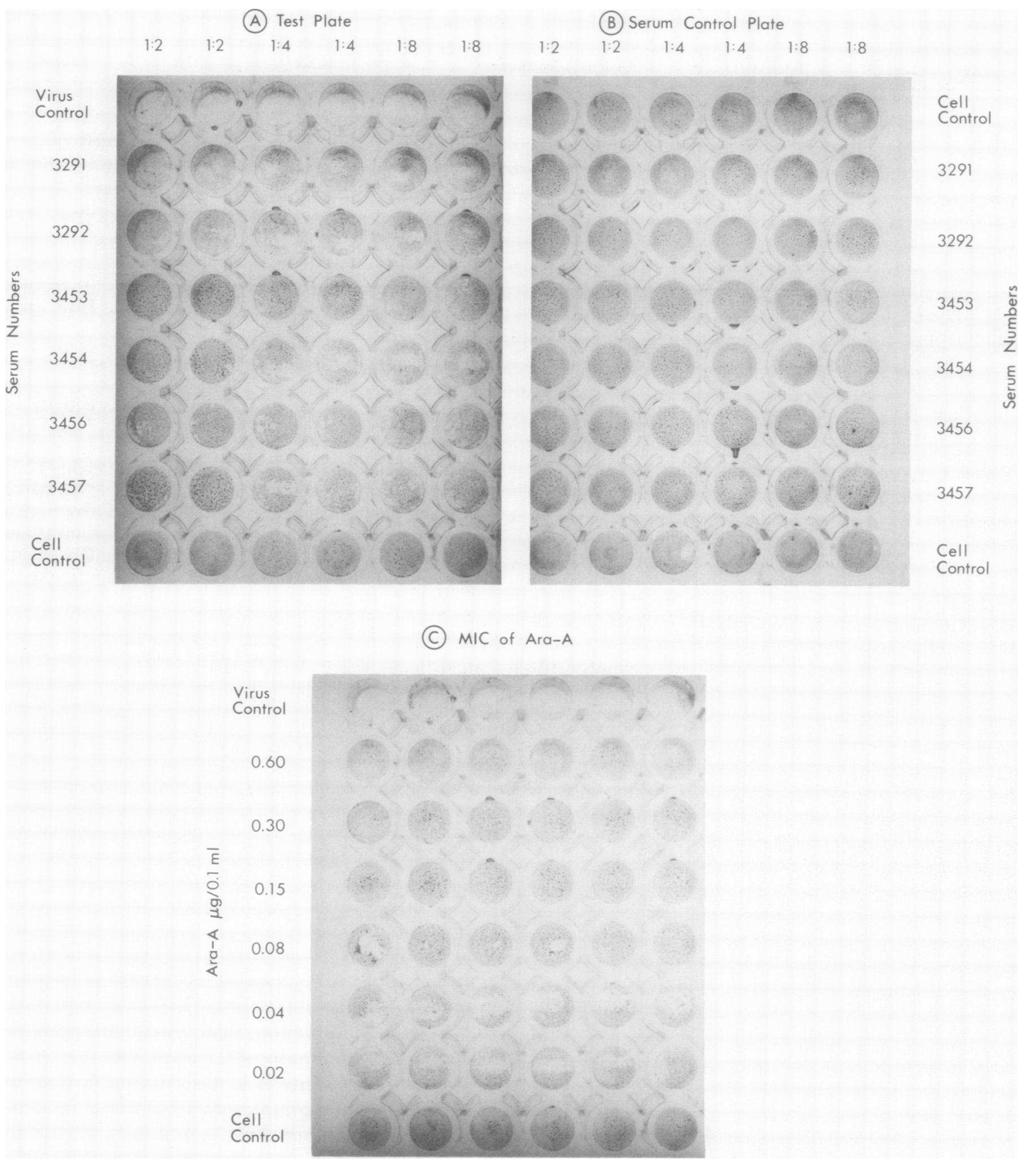

FIgURE 1 Dilutions of serum. Microtiter plates of RK-13 cells from a typical assay of AVA as "ara-A equivalents" are shown. Fully stained wells are present in serum controls (B), cell controls $(\mathrm{A}, \mathrm{B}, \mathrm{C})$, and wells with significant AVA (CPE, $\left.1-2^{+}, \mathrm{A}\right)$. The MIC to ara-A here is $1.5 \mu \mathrm{g} / \mathrm{ml}(\mathrm{C})$. Serum controls from each of the specimens show intact cells (B). Specimens show AVA dilutions of $1: 2$ in sera nos. 3453, 3454, and 3457. Sera nos. 3291, 3292, and 3456 have AVA $\leq 1: 2$ (A). Therefore, the concentrations of AVA in specimens with titers of $1: 2$ is $3 \mu \mathrm{g} / \mathrm{ml}$.

combinations were quantitated as described in Methods. The virus control titered $10^{6.5} \mathrm{TCD}_{50} / 0.1 \mathrm{ml}$, while the synergistic combinations (of ara-A and ara-Hx) had lesser quantities of residual virus (Fig. 3). Therefore, in combination and individual studies with these antiviral compounds, inhibitions of CPE and virus multiplication varied inversely.

To determine the reproducibility of this synergistic 


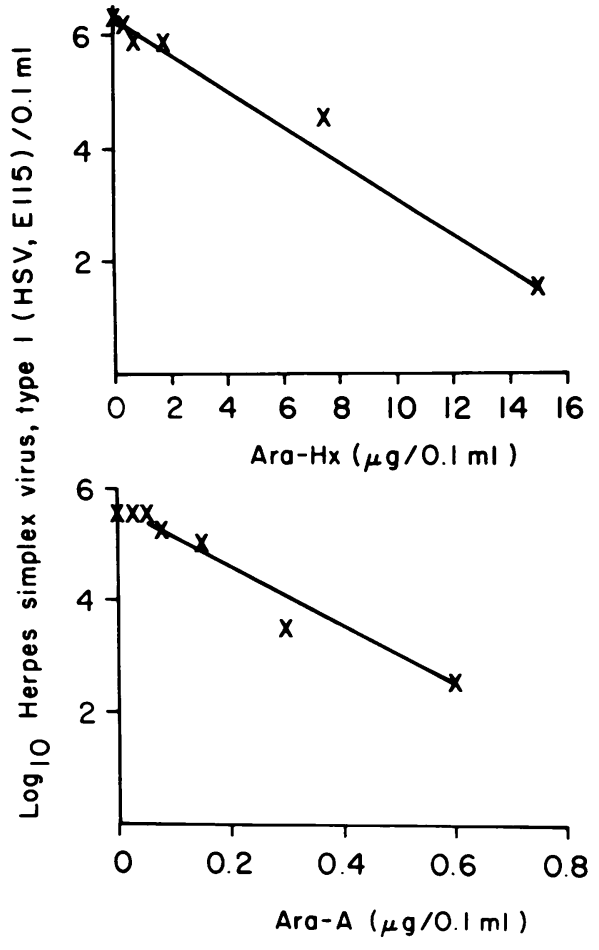

FIGURE 2 Correlation of CPE of HSV-1 in microtiter plates of RK-13 cells and concentrations of ara-A and ara-Hx. Titrations in microtiter plates of MIC determined by inhibition of $\mathrm{CPE}$ as described in the text are correlated with titers of residual HSV-1 (E115). The MIC for ara-A was $0.15 \mu \mathrm{g} / 0.1 \mathrm{ml}$ $(1.5 \mu \mathrm{g} / \mathrm{ml})$ and for ara-Hx, it was $7.5 \mu \mathrm{g} / 0.1 \mathrm{ml}(75$ $\mu \mathrm{g} / \mathrm{ml})$. As can be seen for both ara-A and ara-Hx, the concentration of antiviral agent varies inversely with residual HSV-1. Inhibition of CPE also correlates inversely with residual $\mathrm{HSV}-1$.

effect, similar checkerboard titrations were repeated six times (Table III). The mean of the fractional MIC of the six repititive checkerboard titrations was 0.46 , with a mean "sparing factor" of 0.54 . A Student's $t$ test was done comparing the sum of 0.5 of the MIC of ara-A and ara-Hx with the fractional MIC needed to yield 1 MIC. The combinations required were significantly different $(P \leq 0.05)$.

We repeated the MIC to ara-A and ara- $\mathrm{Hx}$ diluted in whole human serum with a passive hemagglutinating antibody titer to HSV-1 of 1:320. Values were unchanged, e.g., 1.5 and $75 \mu \mathrm{g} / \mathrm{ml}$, respectively. These data again indicate that antiherpes simplex virus antibodies do not affect this AVA, and that neither ara-A nor ara-Hx is significantly bound to serum proteins.

Antiviral activity in sera. Of 85 sera from 10 courses of ara-A assayed by the microtiter method in RK-13 tissue cultures, 56 contained AVA (Table IV). Concentrations in positive samples ranged from 0.8 to $14.4 \mu \mathrm{g} /$ $\mathrm{ml}$ of ara-A equivalents. AVA was found in sera from 9 of the 10 patients, and only three sera were available in the single patient in whom no AVA was de-
TABLE II

Checkerboard Study of AVA of Ara-A and Ara-Hx in Combination Versus HSV-1 (E115) in RK-13

Microtiter Plates

\begin{tabular}{cllllll}
\hline Ara-A & \multicolumn{5}{c}{ HSV-1 (E115), $10^{3.5} \mathrm{TCD}_{\mathrm{s} 0} / 0.1 \mathrm{ml}$} \\
\hline$\mu g / 0.1 \mathrm{ml}$ & & & & & & \\
None & $4+^{*}$ & $4+$ & $4+$ & $4+$ & $4+$ & $4+$ \\
0.60 & 0 & $1+$ & $1+$ & $1+$ & $1+$ & $1+$ \\
0.30 & 0 & $1+$ & $1+$ & $1+$ & $1+$ & $1+$ \\
0.15 & 0 & $1+$ & $1+$ & $1+$ & $1+$ & $2+$ \\
0.08 & 0 & $1+$ & $2+$ & $2+$ & $2+$ & $3+$ \\
0.04 & 0 & $1+$ & $2+$ & $3+$ & $3+$ & $3+$ \\
0.02 & 0 & $1+$ & $2+\ddagger$ & $3+$ & $3+$ & $4+$ \\
Ara-Hx, $\mu \mathrm{g} / 0.1 \mathrm{ml}$ & 7.5 & 3.7 & 1.8 & 0.9 & 0.45 & 0.2 \\
Cell control & 0 & 0 & 0 & 0 & 0 & 0 \\
\hline
\end{tabular}

* Cytopathic effects of HSV-1 in RK-13 cells are graded $1+-4+$. The MIC for ara-A is $0.15 \mu \mathrm{g} / 0.1 \mathrm{ml}(1.5 \mu \mathrm{g} / \mathrm{ml})$, for ara- $\mathrm{Hx}$ it is $7.5 \mu \mathrm{g} / 0.1 \mathrm{ml}(75 \mu \mathrm{g} / \mathrm{ml})$.

$\ddagger 0.02 \mu \mathrm{g} / 0.1 \mathrm{ml}(0.13 \mathrm{MIC})$ ara-A plus $1.8 \mu \mathrm{g} / 0.1 \mathrm{ml}(0.25$ MIC) ara-Hx yield 1 MIC. We interpret this experiment to show synergy. The total input in fractional MIC is 0.38 . The "sparing factor" is $1-0.38=0.62$.

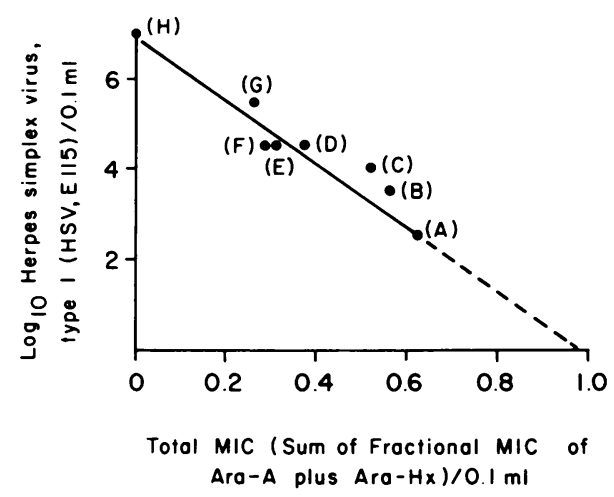

FIGURE 3 Synergy of ara-A and ara-Hx AVA versus HSV-1 (E115) in RK-13 microtiter plates. Fractions of MIC of ara-A and ara-Hx were tested for AVA by inhibition of CPE as described in the text. The MIC of ara-A was $1.5 \mu \mathrm{g} / \mathrm{ml}(0.15$ $\mu \mathrm{g} / 0.1 \mathrm{ml})$ and for ara- $\mathrm{Hx}$, it was $75 \mu \mathrm{g} / \mathrm{ml}(0.75 \mu \mathrm{g} / 0.1 \mathrm{ml})$. For instance, if the combination was $1 / 8$ MIC ara-A plus $1 / 4$ MIC ara-Hx; $0.0188 \mu \mathrm{g}$ ara-A plus $0.938 \mu \mathrm{g}$ ara- $\mathrm{Hx} / 0.1 \mathrm{ml}$ would be present in these microtiter wells. The total MIC which would represent is $3 / 8(0.38)$ MIC. In each combination shown, the actual effect by inhibition of CPE is 1 MIC (see text). The total of the fractional MIC varies inversely with residual HSV-1. Actual values for specific points in the graph are: (A) $1 / 8$ MIC ara-A plus $1 / 2$ MIC ara-Hx $=5 / 8$ (0.63) total MIC, (B) $1 / 16$ MIC ara-A plus $1 / 2$ MIC ara-Hx $=\% 16$ (0.56) total MIC, (C) $1 / 32$ MIC ara-A plus $1 / 2$ MIC ara-Hx = 17/32 (0.53) total MIC, (D) $1 / 8 \mathrm{MIC}$ ara-A plus $1 / 4 \mathrm{MIC}$ ara-Hx $=3 / 8(0.38)$ total MIC, (E) $1 / 16$ MIC ara-A plus $1 / 4$ MIC ara-Hx $=5 / 16(0.31)$ total MIC, (F) 1/32 MIC ara-A plus $1 / 4$ MIC ara-Hx $=9 / 32(0.28)$ total MIC, and (G) $1 / 8 \mathrm{MIC}$ ara-A plus $1 / 8 \mathrm{MIC}$ ara-Hx $=2 / 8(0.25)$ total MIC. 
TABLE III

Effect of Combination of Ara-A and Ara-Hx on Reduction of CPE of HSV-1 (E115) in RK-13 Tissue Cultures

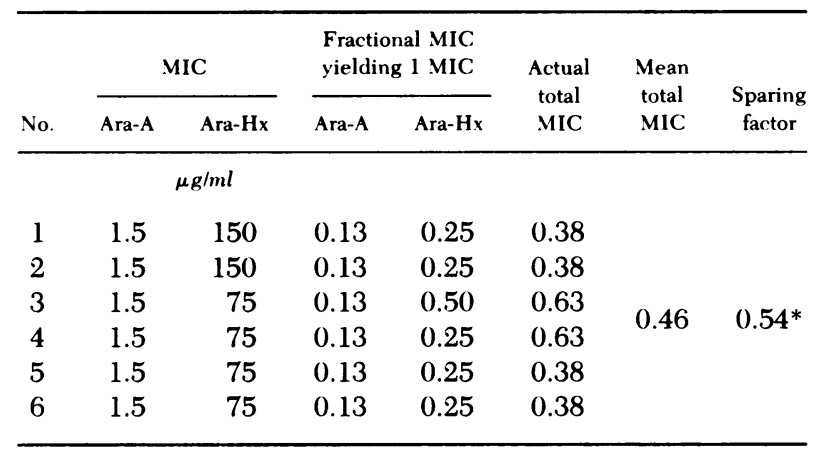

* A Student's $t$ test was done comparing the sum of 0.5 of the MIC of Ara-A and Ara-Hx with the sum of the fractional MIC required to produce $1 \mathrm{MIC}(t=2.83, P \leq 0.05)$.

tected (Table IV, patient 4). A mean of $1.7 \mu \mathrm{g} / \mathrm{ml} \mathrm{AVA}$ was found in this single patient's urine, however.

Intramuscular ara- $\mathrm{A}^{5}$ at doses of 2.5 and $5 \mathrm{mg} / \mathrm{kg}$ daily was given to two patients; 12 of these sera were positive with peaks as high as $6.0 \mu \mathrm{g} / \mathrm{ml}$ occurring $4-6 \mathrm{~h}$ after injections. At $12 \mathrm{~h}$, AVA was low to undetectable. Arithmetic mean concentrations were $1.1 \mu \mathrm{g} / \mathrm{ml}$ in a 29 yr-old man $(2.5 \mathrm{mg} / \mathrm{kg}$ per day), and $0.6 \mu \mathrm{g} / \mathrm{ml}$ in a 9 -yr-old boy $(5.0 \mathrm{mg} / \mathrm{kg}$ per day). The single patient given continuous i.v. infusions of $10.0 \mathrm{mg} / \mathrm{kg}$ of ara-A daily had $3.0 \mu \mathrm{g} / \mathrm{ml}$ AVA within $1 \mathrm{~h}$ after beginning

${ }^{5}$ Ara-A monophosphate may be better absorbed intramuscularly than ara-A, but this derivative was not available. therapy, and this same concentration was found later in the course as well (Table IV, Fig. 4).

We found AVA in 39 of 55 sera from the 7 patients treated intravenously with $20 \mathrm{mg} / \mathrm{kg}$ of ara-A per day. AVA ranged from 0 to $14.4 \mu \mathrm{g} / \mathrm{ml}$, with a mean of 4.1 $\mu \mathrm{g} / \mathrm{ml}$ (Table IV). In general, AVA approached this mean concentration within a few hours after the initiation of ara-A and persisted throughout the course of therapy.

The variation in AVA here by microbiologic assay with a given dosage demands comment. With a single exception (Table I, patient 9) azotemia was not present, and decreases in renal function cannot account for the variations in AVA in serum. Variations in concentrations of AVA may be a result of the following factors. First, although ara-A was infused as a continuous intravenous drip, no special precautions were taken to insure that the rate of delivery was, in fact, constant, and, in all likelihood, it was not. Second, and most importantly, adenosine deaminase which rapidly converts ara-A to ara-Hx is present in human blood, and because an inhibitor of this enzyme could not be added immediately to most of our specimens, a variable metabolism of ara-A in serum continued in vitro (18). Indeed, in patient 10 , to whose specimens covidarabine was promptly added, variation in AVA was markedly less, ranging from 7.2 to $14.4 \mu \mathrm{g} / \mathrm{ml}$ of "ara-A equivalents". In this patient, the mean concentration was 12.9 $\mu \mathrm{g} / \mathrm{ml}$, while in 6 others also receiving a dose of 20 $\mathrm{mg} / \mathrm{kg}$ of ara-A, mean AVA ranged from 0 to $5.8 \mu \mathrm{g} / \mathrm{ml}$. In this regard, samples of serum from patient 10 (as with all of the others) taken before beginning ara-A, both with and without covidarabine, showed no AVA.

T A B LE IV

AVA in Sera of Patients Receiving Ara-A

\begin{tabular}{|c|c|c|c|c|c|c|}
\hline \multirow[b]{2}{*}{ Patient } & \multirow[b]{2}{*}{ Age } & \multirow[b]{2}{*}{ Sex } & \multirow[b]{2}{*}{ Dosage of ara-A } & \multirow[b]{2}{*}{ Route } & \multicolumn{2}{|c|}{ Sera } \\
\hline & & & & & $\begin{array}{l}\text { No. of samples } \\
\text { positive } \div \text { no. of } \\
\text { samples tested }\end{array}$ & $\begin{array}{c}\text { "Ara-A } \\
\text { equivalents" }\end{array}$ \\
\hline & $y r$ & & $m g / k g / d a y$ & & & $\mu g / m l$ \\
\hline 1 & 29 & $\mathbf{M}$ & 2.5 & i.m. & $4 / 9$ & $1.1 *(0-6)$ \\
\hline 2 & 9 & $\mathbf{M}$ & 5.0 & i.m. & $8 / 16$ & $0.6(0-1.5)$ \\
\hline 3 & 58 & $\mathrm{~F}$ & 10.0 & i.v. & $5 / 5$ & $3.0(3.0)$ \\
\hline 4 & 78 & $\mathbf{F}$ & 20.0 & i.v. & $0 / 3$ & $0 \quad(0)$ \\
\hline 5 & 0.01 & $\mathbf{M}$ & 20.0 & i.v. & $1 / 3$ & $0.5(0-1.5)$ \\
\hline 6 & 51 & $\mathbf{F}$ & 20.0 & i.v. & $2 / 5$ & $2.4(0-6.0)$ \\
\hline 7 & 53 & $\mathbf{M}$ & 20.0 & i.v. & $5 / 11$ & $1.6(0-6.0)$ \\
\hline 8 & 64 & $\mathbf{M}$ & 20.0 & i.v. & $6 / 8$ & $5.3(0-12)$ \\
\hline 9 & 55 & $\mathbf{M}$ & 20.0 & i.v. & $11 / 11$ & $5.8(0.8-12.0)$ \\
\hline 10 & 63 & $\mathbf{M}$ & $20.0 \ddagger$ & i.v. & $14 / 14$ & $12.9(7.2-14.4)$ \\
\hline
\end{tabular}

* Arithmetic mean values and ranges in parentheses are listed.

\$ Immediately after collection in this patient, $50 \mu \mathrm{g}$ of an inhibitor of adenosine deaminase (covidarabine, DI) was added for each $10 \mathrm{ml}$ of whole blood. 
Comparisons of AVA in sera by microbiologic and chemical assays. Concentrations of ara-A by HPLC and measures of AVA as ara-A equivalents were done in 52 sera (Table V). Neither method found drug in 10 specimens. In each case where both methods were positive ( 3 times), the microbiologic assay of AVA exceeded chemical determinations of ara-A and ara-Hx. These differences could well result from the combined "bonus" effects described here for ara-A and ara-Hx in RK-13 tissue cultures which are measured microbiologically, but not chemically.

On the other hand, one specimen (Table $\mathrm{V}$, patient 8 , no.- $\left.{ }_{6}\right)^{6}$ had $0.2 \mu \mathrm{g} / \mathrm{ml}$ of ara-A by HPLC and 18.9 $\mu \mathrm{g} / \mathrm{ml}$ of ara-Hx, but no AVA. These concentrations of ara-A and ara-Hx are just at the sensitivity limits of the microbiologic assay (Table II). On the other hand, AVA

${ }^{6}$ This serum was drawn on the 6 th day of treatment with ara-A. This is a random specimen during a constant intravenous infusion of $20 \mathrm{mg} / \mathrm{kg}$ per day.

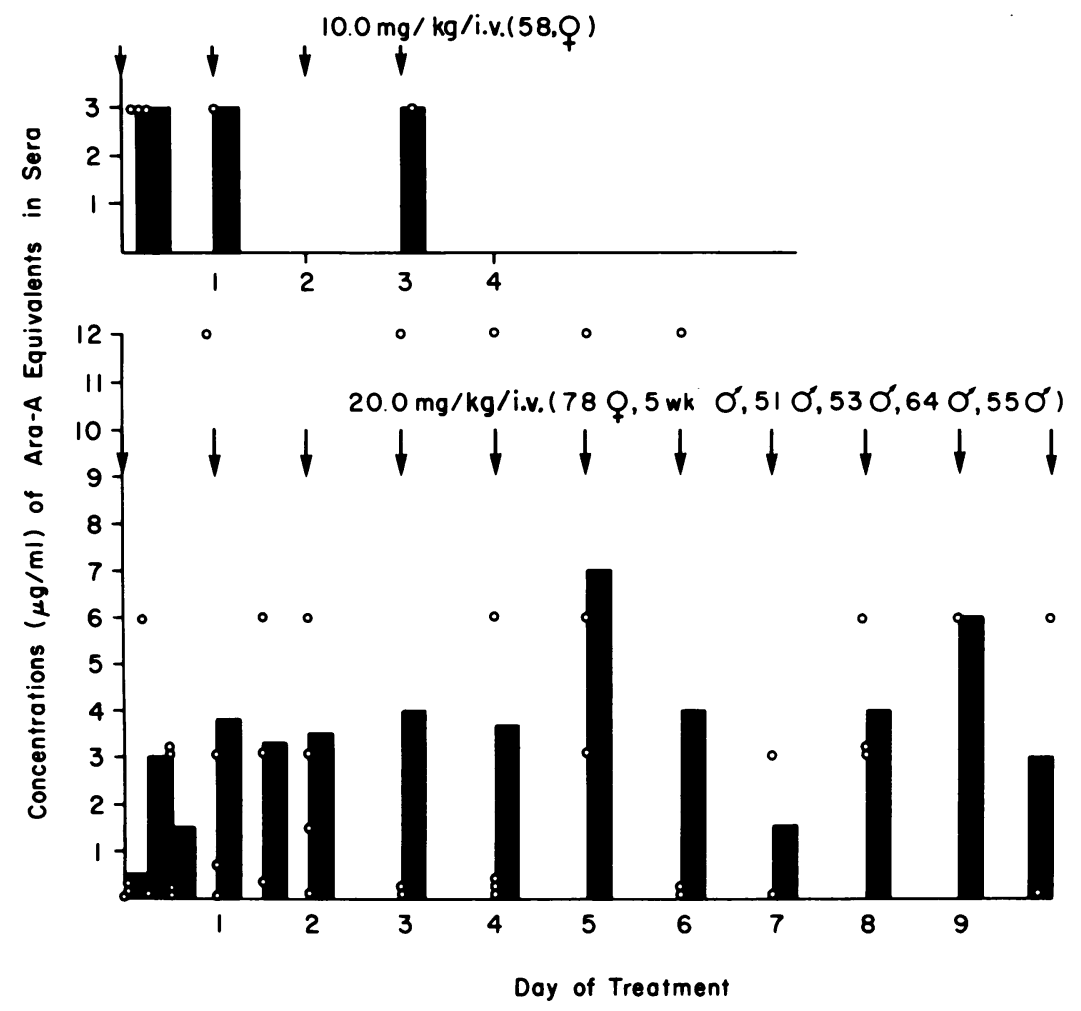

FIGUREs 4 and 5 Concentrations of equivalents of ara- $A$ in sera after parenteral dosing; and urinary excretion of ara-A equivalents after parenteral dosing. AVA as ara-A equivalents in sera and urines of patients receiving intramuscular or intravenous ara-A daily is shown. Covidarabine was not added to these specimens. The dots represent individual determinations, bars are arithmetic means, and patients' ages (yr) are shown in parentheses (Fig. 4). Urine values (Fig. 5) are concentrations per total collections over periods of $4 \mathrm{~h}$.
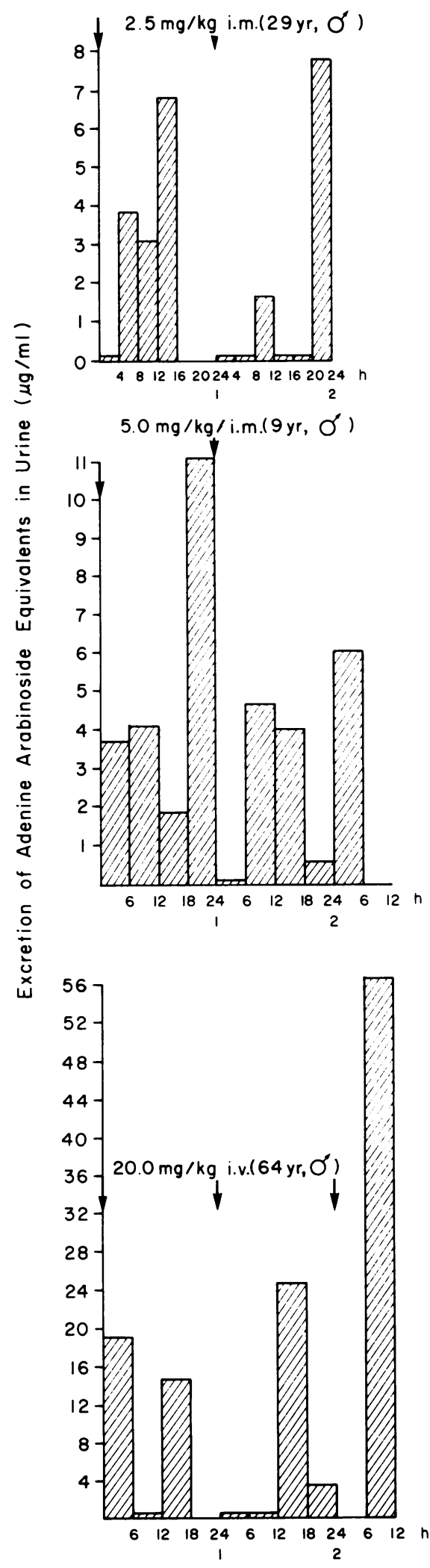

Day of Treatment 
TABLE V

Comparison of Assays of Human Sera for Ara-A Metabolites by Bioassay and HPLC

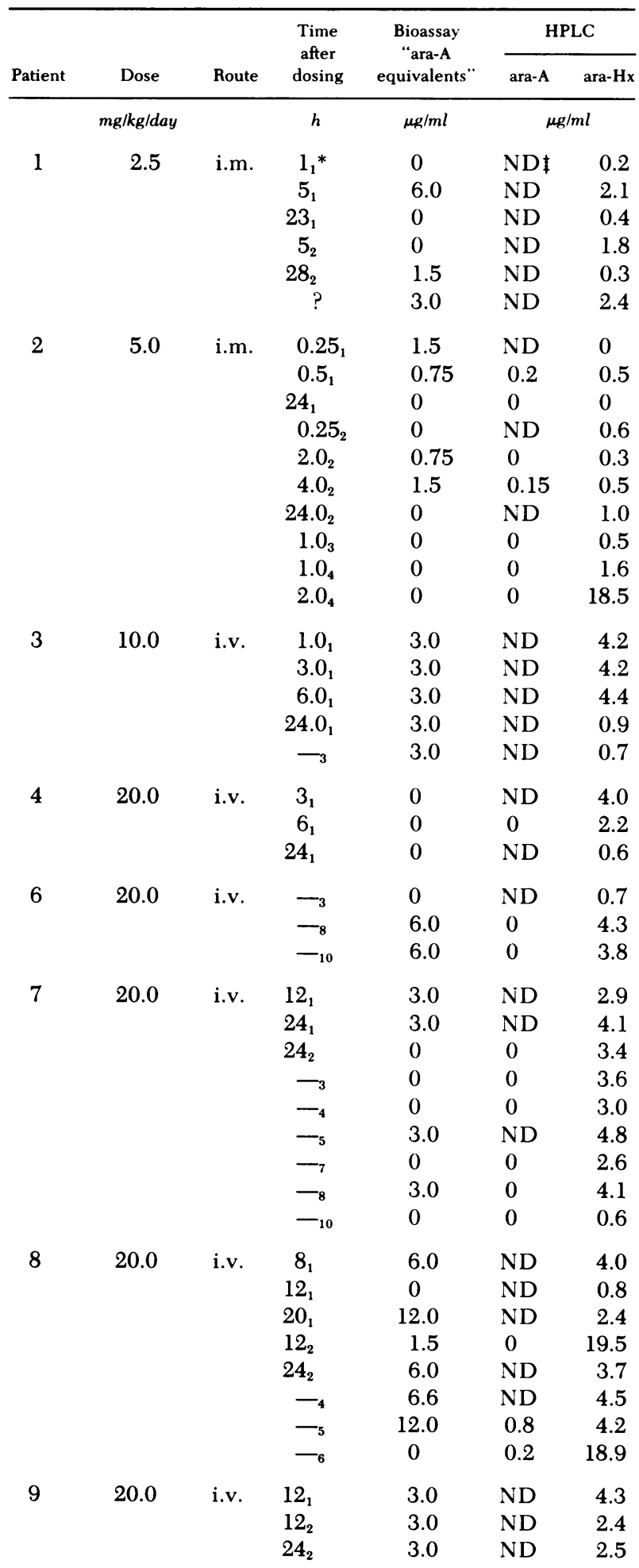

TABLE V (Continued)

\begin{tabular}{|c|c|c|c|c|c|c|}
\hline \multirow[b]{2}{*}{ Patient } & \multirow[b]{2}{*}{ Dose } & \multirow[b]{2}{*}{ Route } & \multirow{2}{*}{$\begin{array}{l}\text { Time } \\
\text { after } \\
\text { dosing }\end{array}$} & \multirow{2}{*}{$\begin{array}{c}\text { Bioassay } \\
\text { “ara-A } \\
\text { equivalents" }\end{array}$} & \multicolumn{2}{|c|}{ HPLC } \\
\hline & & & & & ara-A & ara-Hx \\
\hline & $m g / k g / d a !$ & & $h$ & $\mu g / m l$ & \multicolumn{2}{|c|}{$\mu g / m l$} \\
\hline & & & -3 & 12.0 & ND & 2.6 \\
\hline & & & -4 & 12.0 & ND & 5.0 \\
\hline & & & $-_{5}$ & 6.0 & ND & 3.7 \\
\hline & & & $-{ }_{6}$ & 12.0 & ND & 1.1 \\
\hline & & & -7 & 3.0 & ND & 2.4 \\
\hline
\end{tabular}

* Subscript indicates day of treatment with ara-A.

$\ddagger$ Not determined.

ranging from 1.5 to $6.0 \mu \mathrm{g} / \mathrm{ml}$ was detected in 5 sera which contained no detectable ara-A by HPLC. Each of these latter sera contained ara-Hx by HPLC, but none of the chemical values individually account for the AVA found.

52 specimens were analyzed for ara- $\mathrm{Hx}$ by HPLC and 50 contained this compound. Of the 52 specimens, 32 had AVA by microbiologic assay. Again, concentrations of ara-Hx alone could not account for the totality of the antiherpesvirus effects observed.

AVA in urines. Of the 106 urinary aliquots assayed for AVA, 61 had concentrations ranging from 3.7 to 60 $\mu \mathrm{g} / \mathrm{ml}$ (Table VI). Patients 1 and 2 , receiving i.m. injections had 15 of 22 specimens with $1.5-30 \mu \mathrm{g} / \mathrm{ml}$. AVA appeared in urine within $6 \mathrm{~h}$, and persisted until the next parenteral injection. 44 of 76 urines from 6 patients treated by continuous i.v. infusions of $20 \mathrm{mg} / \mathrm{kg}$ per day of ara-A contained 3.7-60.0 $\mu \mathrm{g} / \mathrm{ml}$ as AVA. With succeeding days, concentrations of urinary AVA did not increase (Fig. 5). Unfortunately, urines were not systematically collected after completion of treatment, but a single patient had $7.5 \mu \mathrm{g} / \mathrm{ml}$ of AVA in a random urine 7 days after completing an 8-day course $(20 \mathrm{mg} / \mathrm{kg}$ per day, i.v.). We could not calculate urinary clearances, nor percents of drug excreted in urine because AVA does not correlate stoichiometrically with moles of either ara-A or ara-Hx.

Clinical findings. Within 9 days after ara-A was begun, every patient, with the possible exceptions of the infant with congenital cytomegalovirus infection and the 63-yr-old man with herpes simplex virus encephalitis, improved (Table I). Patients 2 and 8 with disseminated herpes simplex virus infections appear to have had the course of their infections dramatically improved, while the others recovered more slowly.

Toxic reactions. No significant changes in liver, kidney, or cardiac functions occurred. Hematologic changes were noted most often in patients with concomitant underlying chronic diseases and with 20$\mathrm{mg} / \mathrm{kg}$ doses of ara-A daily. 
TABLE VI

AVA in Urines of Patients Receiving Ara-A

\begin{tabular}{|c|c|c|c|c|c|c|}
\hline \multirow[b]{2}{*}{ Patient } & \multirow[b]{2}{*}{ Age } & \multirow[b]{2}{*}{ Sex } & \multirow[b]{2}{*}{ Dosage of ara-A } & \multirow[b]{2}{*}{ Route } & \multicolumn{2}{|c|}{ Sera } \\
\hline & & & & & $\begin{array}{l}\text { No. of samples } \\
\text { positive } \div \text { no. of } \\
\text { samples tested }\end{array}$ & $\begin{array}{c}\text { "Ara-a } \\
\text { equivalents" }\end{array}$ \\
\hline & $y r$ & & $m g / k g / d a y$ & & \multicolumn{2}{|c|}{$\mu g / m l$} \\
\hline 1 & 29 & $\mathbf{M}$ & 2.5 & i.m. & $7 / 13$ & $10.1(0-30)$ \\
\hline 2 & 9 & $\mathbf{M}$ & 5.0 & i.m. & $8 / 9$ & $11.2(0-15)$ \\
\hline 3 & 58 & $\mathbf{F}$ & 10.0 & i.v. & $2 / 8$ & $1.9(0-7.5)$ \\
\hline 4 & 78 & $\mathbf{F}$ & 20.0 & i.v. & $4 / 9$ & $1.7(0-3.8)$ \\
\hline 5 & 0.01 & $\mathbf{M}$ & 20.0 & i.v. & $1 / 9$ & $1.7(0-15.0)$ \\
\hline 6 & 51 & $\mathbf{F}$ & 20.0 & i.v. & $3 / 15$ & $2.5(0-30)$ \\
\hline 7 & 53 & $\mathbf{M}$ & 20.0 & i.v. & $16 / 17$ & $7.5(0-15)$ \\
\hline 8 & 64 & $\mathbf{M}$ & 20.0 & i.v. & $6 / 12$ & $12.5(0-60)$ \\
\hline 9 & 55 & $\mathbf{M}$ & 20.0 & i.v. & $14 / 14$ & $7.2(3.7-15.0)$ \\
\hline 10 & 63 & $\mathbf{M}$ & $20.0^{*}$ & i.v. & ND $\ddagger$ & - \\
\hline
\end{tabular}

* Immediately after collection in this patient, $50 \mu \mathrm{g}$ of an inhibitor of adenosine deaminase (covidarabine, DI) was added for each $10 \mathrm{ml}$ of whole blood.

$\$$ Not determined.

Each of the six patients receiving $20 \mathrm{mg} / \mathrm{kg}$ per day of ara-A had falls in hemoglobin of $>2 \mathrm{~g} / 100 \mathrm{ml}$, while only one of the three patients receiving $10 \mathrm{mg} / \mathrm{kg}$ per day had a similar fall. Bone marrows were not examined in any of these patients, but in others megaloblasts have been seen. In three patients at the time ara-A was begun, platelets were $<150,000 / \overline{\mathrm{mm}}^{3}$, leukocyte counts were $<4,500 / \mathrm{mm}^{3}$, and absolute polymorphonuclear numbers were $<2,500 / \mathrm{mm}^{3}$. With ara-A, further falls in these parameters did not occur.

Two patients with stage IVB Hodgkin's disease developed transient trance-like conditions resembling akinetic mutism. Their courses have been described (8).

\section{DISCUSSION}

The pharmacokinetic findings reported here add significant information to our understanding of the antiviral effects of ara-A in humans. AVA by this microbiologic assay with a sensitivity of $1.5 \mu \mathrm{g} / \mathrm{ml}$ of ara-A equivalents is dependent upon antiherpesvirus activity of ara-A and ara-Hx. The assay adds the specimen to be tested for AVA after the complete absorption of the virus challenge, and thus is not affected by the concomitant presence of homotypic antibody in sera. Likewise, the use of heterologous rabbit cells frees the assay from interference by human interferon (11).

This new microbiologic assay of AVA as a result of parenteral administration of ara- $\mathrm{A}$ is based upon the inhibition of CPE of HSV-1. The method correlates with the observed in vitro inhibition of HSV-1 multiplication, and the therapeutic effectiveness of ara-A. Earlier
HPLC (10) or radioactive labeling techniques (9) measuring single nucleosides have not predicted the benefits to patients which have been carefully observed. Combined, ara- $\mathrm{A}$ and ara-Hx are synergistic antiviral agents in RK-13 cells in vitro, and this fact probably accounts for differences between chemical and microbiologic assays in vivo which are reported here. Similarly, antiviral synergy has already been shown for vero renal cells with several strains of HSV-1 with ara-A and human interferon (17), but a similar effect remains to be demonstrated in vitro in human tissue cultures. Indeed, AVA of drugs in combination must be clearly defined for each system by specifying $(a)$ virus challenge, $(b)$ its titer, and $(c)$ the cell system used. Only then can results of microbiologic assays done in different laboratories be compared. In this regard, with different tissue cultures with a different virus (herpes simplex virus, type 2), human interferon and ara-A in human skin fibroblast cultures do not demonstrate antiviral synergy $(18,19)$.

The mechanism of the combined effects of the antiviral drugs, ara-A and ara-Hx are unknown. Ara-A inhibits herpesvirus polymerase $(20,21)$, but the mode of action of ara-Hx is not clear.

At an i.v. dosage of $20 \mathrm{mg} / \mathrm{kg}$ per day AVA, as ara-A equivalents, was maintained throughout the course of therapy at a mean level of $12.9 \mu \mathrm{g} / \mathrm{ml}$ in the single patient to whose specimens of blood covidarabine was promptly added to inhibit in vitro degradation of ara-A to its hypoxanthine derivative. When covidarabine was immediately added to bloods, and $20 \mathrm{mg} / \mathrm{kg}$ per day of ara-A was given, the mean concentration in serum was 
$4.1 \mu \mathrm{g} / \mathrm{ml}$. Significant persisting serum AVA as a result of ara-A and ara- $\mathrm{Hx}$ contrasts remarkably with the transient or insignificant values which we found in patients receiving earlier candidate antiviral drugs, cytosine arabinoside and idoxuridine $(8,11,22)$. Sustained antiherpesvirus therapeutic concentrations in human sera correlate with the salutary effects of courses of ara-A reported in patients with herpes zoster and herpes simplex virus encephalitis $(2,3)$. Urinary excretion of parenterally administered ara-A is estimated as $52 \%$, but the half-life of ara-A has not yet been determined by chemical studies (10). Ara-A is taken up by cells and the erythrocyte has been best studied to date (9). The site of action of ara-A is, of course, intracellular, probably after phosphorylation $(9,20)$. Measures of AVA at intracellular loci along with further studies of sera and urines are needed.

Clinical responses observed here are not a blinded clinical trial and cannot be used to judge the efficacy of ara-A. However, during two separate uses of ara-A, the course of a newborn with congenital cytomegalovirus disease was unchanged. Ch'ien et al. have suggested that subtoxic dosages of ara-A suppress urinary excretion of cytomegalovirus, but that the clinical response depends upon the duration and extensiveness of disease in the patient $(23,24)$. Our two patients with generalized cutaneous HSV-1 infections seem to have clearly been helped. New vesicles did not form after 48-72 $\mathrm{h}$ of ara-A, and by the 6th day lesions had only erythematous bases remaining. In this regard, $\mathrm{Ch}^{\prime}$ ien, et al. found that when $10 \mathrm{immunosuppressed} \mathrm{patients}$ with severe mucocutaneous herpes simplex virus infections received $3.3-10 \mathrm{mg} / \mathrm{kg}$ per day of i.v. ara-A for 5-13 days, HSV-1 excretion was reduced by $90 \%$ within $72 \mathrm{~h}$ (5). In this study, by 9 days lesions contained no virus and were healed.

The falls in hemoglobin in all six patients receiving ara- $\mathrm{A}$ at $20 \mathrm{mg} / \mathrm{kg}$ per day, and the transient bizarre neurologic states seen in two of these patients suggest that this dosage is near to that which is maximum and tolerable. Further studies of ara-A and other candidate antiviral agents should include pharmacokinetic data such as those reported here.

\section{ACKNOWLEDGMENTS}

This study was aided by the National Institute of Allergy and Infectious Diseases grant AI 00261-13, the National Institute of Neurological Diseases and Stroke grant NS 11455-06, the Skillman Foundation, the Michigan Foundation for Infectious Diseases, and the Veterans Administration.

\section{REFERENCES}

1. Abel, R., Jr., H. E. Kaufman, and J. Sugar. 1975. Intravenous adenine arabinoside against herpes simplex keratouveitis in humans. Am. J. Ophthalmol. 79: 659-664.
2. Whitley, R., S. Soong, R. Dolin, G. J. Galasso, L. T. Ch'ien, C. A. Alford, Jr., and The Collaborative Study Group. 1977. Adenine arabinoside therapy of herpes simplex encephalitis. N. Engl. J. Med. 297: 289-294.

3. Whitley, R. J., L. T. Ch'ien, R. Dolin, G. J. Galasso, C. A. Alford, Jr., editors, and The Collaborative Study Group. 1976. Adenine arabinoside therapy of herpes zoster in the immunosuppressed. N. Engl. J. Med. 294: 1193-1199.

4. Ch'ien, L. T., R. J. Whitley, A. J. Nahmias, E. B. Lewin, C. C. Linnemann, Jr., L. D. Frenkel, J. A. Bellanti, R. A. Buchanan, and C. A. Alford, Jr. 1975. Antiviral chemotherapy and neonatal herpes simplex virus infection: A pilot study - experience with adenine arabinoside (Ara-A). Pediatrics. 55: 678-685.

5. Ch'ien, L. T., N. J. Cannon, L. J. Charamella, W. E. Dismukes, R. J. Whitley, R. A. Buchanan, and C. A. Alford, Jr. 1973. Effect of adenine arabinoside on severe herpesvirus hominis infections in man. J. Infect. Dis. 128: 658663.

6. Koplan, J. P., K. A. Monsur, S. O. Foster, F. Huq, M. M. Rahaman, S. Huq, R. A. Buchanan, and N. A. Ward. 1975. Treatment of variola major with adenine arabinoside. J. Infect. Dis. 131: 34-39.

7. Baublis, J. V., R. J. Whitley, L. T. Ch'ien, and C. A. Alford, Jr. 1975. Treatment of cytomegalovirus infection in infants and adults. In Adenine arabinoside: An antiviral agent. D. Pavan-Langston, R. A. Buchanan, and C. A. Alford, Jr., editors. Raven Press, New York. 247-260.

8. Lauter, C. B., E. J. Bailey, and A. M. Lerner. 1976. Microbiologic assays and neurological toxicity during use of adenine arabinoside in humans.J. Infect. Dis. 134: 75-79.

9. Glazko, A. J., T. Chang, J. C. Drach, D. R. Mourer, P. E. Borondy, H. Schneider, L. Croskey, and E. Maschewske. 1975. Species differences in the metabolic disposition of adenine arabinoside. In Adenine arabinoside: An antiviral agent. D. Pavan-Langston, R. A. Buchanan, C. A. Alford, Jr., editors. Raven Press, New York. 111-133.

10. Kinkel, A. W., and R. A. Buchanan. 1975. Human Pharmacology. In Adenine arabinoside: An antiviral agent. D. Pavan-Langston, R. A. Buchanan, C. A. Alford, Jr., editors. Raven Press, New York. 197-204.

11. Lerner, A. M., and E. J. Bailey. 1972. Concentrations of idoxuridine in serum, urine, and cerebrospinal fluid of patients with suspected diagnoses of Herpesvirus hominis encephalitis. J. Clin. Invest. 51: 45-49.

12. Williams, B. B., and A. M. Lerner. 1975. Antiviral activity of an adenosine deaminase inhibitor: Decreased replication of herpes simplex virus. J. Infect. Dis. 131: 673-677.

13. Woo, P., W. K. Dion, H. W. Lange, L. F. Dahl, and L. J. Durham. 1974. A novel adenosine and ara-A deaminase inhibitor (R)-3-(2-deoxy- $\beta$-D-erythro-pentofuranosyl)-3,6, 7,8-tetrahydroimidazo (4,5-d) $(1,3)$ diazepin-8-al. $J$. Heterocycl. Chem. 11: 641-643.

14. Lerner, A. M., C. B. Lauter, D. C. Nolan, and M. J. Shippey. 1972. Passive hemagglutinating antibodies in cerebrospinal fluids in Herpesvirus hominis encephalitis. Proc. Soc. Exp. Biol. Med. 140: 1460-1466.

15. Lerner, A. M., M. J. Shippey, and L. R. Crane. 1974. Serologic responses to herpes simplex virus in rabbits: Complement-requiring neutralizing, conventional neutralizing, and passive hemagglutinating antibodies. $J$. Infect. Dis. 129: 623-636.

16. Lerner, A. M., and E. J. Bailey. 1976. Differential sensitivity of herpes simplex virus types 1 and 2 to human interferon: Antiviral effects of interferon plus $9-\beta-D$ arabinofuranosyladenine. J. Infect. Dis. 134: 400-404. 
17. Lerner, A. M., and E. J. Bailey. 1974. Synergy of 9- $\beta$-Darabinofuranosyladenine and human interferon against herpes simplex virus, type I. J. Infect. Dis. 130: 549-552.

18. Bryson, Y., J. D. Connor, L. Sweetman, S. Carey, M. A. Stuckey, and R. Buchanan. 1974. Determination of plaque inhibitory activity of adenine arabinoside (9- $\beta$-Darabinofuranosyladenine) for herpesvirus using an adenosine deaminase inhibitor. Antimicrob. Agents Chemother. 6: $98-101$.

19. Bryson, Y., and L. H. Kronenberg. 1977. Combined antiviral effects of interferon, adenine arabinoside, hypoxanthine arabinoside, and adenine arabinoside-5'-monophosphate in human fibroblast cultures. Antimicrob. Agents Chemother. 11: 299-306.

20. Shipman, C., Jr., S. H. Smith, R. H. Carlson, and J. C. Drache. 1976. Antiviral activity of arabinosyladenine and arabinosylhypoxanthine in herpes simplex virus-infected $\mathrm{KB}$ cells: Selective inhibition of viral deoxyribonucleic acid synthesis in synchronized suspension cultures. Antimicrob. Agents Chemother. 9: 120-127.

21. Williams, B. B., E. J. Bailey, and A. M. Lerner. 1977. Inhibitory and lethal concentrations of $9-\beta$-D-arabinofuranosyladenine and its hypoxanthine-derivative versus herpes simplex virus type 1. J. Lab. Clin. Med. 89: 687-691.

22. Lauter, C. B., E. J. Bailey, and A. M. Lerner. 1974. Assessment of cytosine arabinoside as an antiviral agent in humans. Antimicrob. Agent Chemother. 6: 598-602.

23. Ch'ien, L. T., N. J. Cannon, R. J. Whitley, A. G. Diethelm, W. E. Dismukes, C. W. Scott, R. A. Buchanan, and C. A. Alford, Jr. 1974. Effect of adenine arabinoside on cytomegalovirus infections. J. Infect. Dis. 130: 32-38.

24. Levine, D. P., C. B. Lauter, and A. M. Lerner. 1978. Simultaneous serum and cerebrospinal fluid antibodies in herpes simplex virus encephalitis. JAMA (J. Am. Med. Assoc.). 240: 356-360. 